\title{
Rozdzial
}

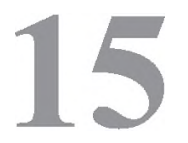

\section{Czy porządki emerytalne różnią się pod względem redystrybucji?}

\author{
Joanna Rutecka
}

Bazując na analizach przeprowadzonych w rozdziałach 4 i 10 oraz ustaleniach poczynionych $\mathrm{w}$ rozdziale $12, \mathrm{w}$ niniejszym rozdziale określone wcześniej grupy krajów (przyporządkowane uprzednio do poszczególnych porządków emerytalnych) poddano ocenie pod względem poziomu występującej w nich redystrybucji, ze szczególnym uwzględnieniem zastosowanych mechanizmów transferu dochodów. Służy to weryfikacji hipotezy badawczej $\mathrm{H} 3$, zgodnie z którą relacja między państwem a rynkiem w systemie emerytalnym wpływa na stopień, rodzaj i kierunek transferów redystrybucyjnych.

Na wstępie warto zaznaczyć, że poziom redystrybucji w systemie emerytalnym zależy przede wszystkim od zastosowanej formuły emerytalnej i narzędzi użytych w celu „złagodzenia” czystej ekwiwalentności składek i świadczeń, tj. poluzowania związku między wysokością wpłaconej przez uczestnika systemu składki i oferowanego świadczenia, które w czystej formule aktuarialnej zależą od indywidualnego ryzyka danej osoby. Formuły, które w mniejszym stopniu uwzględniają zasadę proporcjonalności oraz równoważności składek i świadczeń, mają charakter bardziej redystrybucyjny niż te odzwierciedlające zasadę równowartości między skapitalizowaną wartością składek oraz zdyskontowaną wartością świadczeń. Do pierwszej $\mathrm{z}$ grup zaliczyć należy formuły o zdefiniowanym świadczeniu (DB, w tym flat-rate), a do drugiej - formuły o zdefiniowanej składce (DC).

Pierwsza wyodrębniona grupa krajów, tworząca porządek emerytalny (I) $\mathrm{z}$ istotnym udziałem dobrowolności uczestnictwa, charakteryzuje się relatywnie wysokim udziałem dobrowolnych planów emerytalnych w dochodach uzyskiwanych w okresie starości. Obejmuje ona: Kanadę, Wielką Brytanię, Stany Zjednoczone, Irlandię, Czechy oraz Nową Zelandię. W krajach tych (z wyjątkiem Stanów Zjednoczonych) bazowy system emerytalny oferuje emeryturę obywatelską (kwotową), mającą charakter świadczenia rezydualnego lub uzależnionego od spełnienia wa- 
runku stażowego. Świadczenie to jest uzupełniane emeryturą publiczną opartą na formule DB (wyjątkiem jest Irlandia i Nowa Zelandia), której wysokość zależy od długości okresu składkowego i poziomu wynagrodzeń. W Stanach Zjednoczonych publiczny system emerytalny oparty jest na emeryturze wypłacanej według formuły zdefiniowanego świadczenia, brak jest natomiast emerytury obywatelskiej czy gwarancji emerytury minimalnej (tab. 15.1). Biorąc pod uwagę formułę emerytalną stosowaną w I filarze, kraje należące do porządku emerytalnego (I) wydają się posiadać systemy dokonujące silnej redystrybucji, jednak jej głębokość zależy oczywiście od rozmiarów samego systemu publicznego.

W drugiej grupie krajów, tj. zakwalifikowanych do porządku emerytalnego (II) $\mathrm{z}$ istotnym udziałem obowiązkowości uczestnictwa $\mathrm{w}$ planach emerytalnych administrowanych przez sektor prywatny, także występuje emerytura obywatelska (Australia, Dania, Estonia, Holandia, Islandia, Izrael, Szwecja) lub minimalna (Polska, Szwajcaria), jednak świadczenie bazowe pochodzi głównie z części zarządzanej przez instytucje prywatne lub łącznie podmioty publiczne i prywatne. Pod względem formuł użytych do wyznaczania bazowego świadczenia ta grupa krajów jest niejednorodna - bazowa emerytura, oparta na różnych metodach finansowania, może wykorzystywać zasadę DB, DC lub NDC. Trudno zatem formułować przypuszczenia o poziomie redystrybucji emerytalnej typowej dla przedstawicieli tej grupy. Częste występowanie formuły DC sugeruje jednak, że redystrybucja w porządku emerytalnym (II) jest ogólnie niższa niż w porządku emerytalnym (I).

Kraje przypisane do porządku (III) obowiązkowych emerytur administrowanych publicznie w ramach systemu obowiązkowego oferują zazwyczaj emeryturę opartą na formule zdefiniowanego świadczenia uzupełnioną gwarancją emerytury minimalnej (Belgia, Francja, Hiszpania, Luksemburg, Portugalia, Hiszpania, Turcja i Węgry) lub - rzadziej - emeryturą obywatelską (Finlandia, Grecja, Luksemburg). Od ogólnego obrazu tej grupy państw odbiegają Norwegia i Włochy, w których bazowe systemy emerytalne wykorzystują formułę zdefiniowanej składki, zarówno finansowej (FDC), jak i niefinansowej (NDC). Kraje o znacznej roli obowiązkowego systemu zarządzanego publicznie $\mathrm{w}$ dostarczaniu dochodów emerytalnych wydają się również dokonywać znacznej redystrybucji, biorąc pod uwagę sposób obliczania świadczeń (DB) oraz rozmiary systemu publicznego. Od krajów z porządku emerytalnego (I) różnią się częstszym występowaniem emerytury minimalnej (przyznawanej, gdy świadczenie bazowe nie osiąga poziomu minimalnego i przy spełnieniu warunku stażowego), znacznie rzadziej występuje natomiast emerytura obywatelska (flat-rate). 
Tabela 15.1. Rodzaje i formuly emerytur bazowych oferowanych w pierwszym filarze systemów emerytalnych w wybranych krajach OECD

\begin{tabular}{|c|c|c|c|c|}
\hline Kraj & $\begin{array}{l}\text { Emerytura } \\
\text { obywatelska }\end{array}$ & $\begin{array}{l}\text { Emerytura } \\
\text { minimalna }\end{array}$ & $\begin{array}{c}\text { System } \\
\text { zarządzany } \\
\text { przez państwo }\end{array}$ & $\begin{array}{c}\text { System } \\
\text { zarządzany } \\
\text { prywatnie }\end{array}$ \\
\hline 1 & 2 & 3 & 4 & 5 \\
\hline \multicolumn{5}{|c|}{ Porządek emerytalny (I) } \\
\hline Czechy & $x$ & $\mathrm{x}$ & DB & \\
\hline Irlandia & $x$ & & & \\
\hline Kanada & $\mathrm{x}$ & & DB & \\
\hline Nowa Zelandia & $x$ & & & \\
\hline Stany Zjednoczone & & & $\mathrm{DB}$ & \\
\hline Wielka Brytania & $x$ & & DB & \\
\hline \multicolumn{5}{|c|}{ Porządek emerytalny (II) } \\
\hline Australia & $\mathrm{X}$ & & & $D C$ \\
\hline Dania & $x$ & & & $\mathrm{DC}$ \\
\hline Estonia & $x$ & & Punkty & $\mathrm{DC}$ \\
\hline Holandia & $x$ & & & $\mathrm{DB}$ \\
\hline Islandia & $x$ & & & $\mathrm{DB}$ \\
\hline Izrael & $x$ & & & $\mathrm{DC}$ \\
\hline Polska & & $\mathrm{x}$ & NDC & $D C$ \\
\hline Stowacja & & & Punkty & $\mathrm{DC}$ \\
\hline Szwajcaria & & $\mathrm{X}$ & $\mathrm{DB}$ & $\mathrm{DB}$ \\
\hline Szwecja & $x$ & & NDC & $\mathrm{DC}$ \\
\hline \multicolumn{5}{|c|}{ Porządek emerytalny (III) } \\
\hline Austria & & & $\mathrm{DB}$ & \\
\hline Belgia & & $\mathrm{x}$ & $\mathrm{DB}$ & \\
\hline Finlandia & $x$ & & $\mathrm{DB}$ & \\
\hline Francja & & $X$ & $\mathrm{DB}+$ Punkty & \\
\hline Grecja & $x$ & & $\mathrm{DB}$ & \\
\hline Hiszpania & & $x$ & $\mathrm{DB}$ & \\
\hline
\end{tabular}




\begin{tabular}{|l|c|c|c|c|}
\hline \multicolumn{1}{|c|}{$\mathbf{1}$} & $\mathbf{2}$ & $\mathbf{3}$ & $\mathbf{4}$ & $\mathbf{5}$ \\
\hline Luksemburg & $\mathrm{X}$ & $\mathrm{X}$ & DB & \\
\hline Niemcy & & & Punkty & \\
\hline Norwegia & $\mathrm{X}$ & & NDC & DC \\
\hline Portugalia & & $\mathrm{X}$ & DB & \\
\hline Slowenia & & $\mathrm{X}$ & DB & \\
\hline Turcja & & $\mathrm{X}$ & DB & \\
\hline Węgry & & $\mathrm{X}$ & DB & \\
\hline Włochy & & $\mathrm{X}$ & NDC & \\
\hline
\end{tabular}

Źródło: opracowanie własne na podstawie [OECD, 2015].

Faktyczny poziom redystrybucji występujący w całym systemie emerytalnym zależy nie tylko od formuły zastosowanej w systemie obowiązkowym, ale także od rozmiarów tej części systemu. Jeśli bazowy (obowiązkowy) system emerytalny jest relatywnie niewielki, to nawet jeśli jest silnie redystrybucyjny, nie będzie równie mocno wpływać na wyrównanie wszystkich dochodów emerytalnych. Jeśli natomiast system obowiązkowy dostarcza niemal całości dochodów w okresie starości, wykorzystane w nim narzędzia redystrybucyjne będą miały niemal pełne przełożenie na dystrybucję dochodów uzyskiwanych przez uczestników w okresie starości.

Poziom emerytury obywatelskiej oferowanej w systemie publicznym różni się znacznie między analizowanymi krajami (rys. 15.1). W pierwszej grupie krajów emerytura obywatelska wynosi od $9 \%$ (Czechy) do $40 \%$ przeciętnych zarobków (Nowa Zelandia). Niemal równie wysokie świadczenia oferowane są w Irlandii (ok. 35\% przeciętnej płacy), a znacznie niższe w Wielkiej Brytanii i Kanadzie (odpowiednio $16,5 \%$ i $13,7 \%$ ). Emerytura obywatelska oferowana w tych krajach zależy od spełnienia warunku zamieszkiwania na terenie danego kraju przez określony czas (Nowa Zelandia, Kanada) lub opłacania składek przez co najmniej wymagany okres (Czechy, Irlandia, Wielka Brytania).

W porządku emerytalnym (II), czyli w grupie krajów o wysokim udziale obowiązkowych emerytur prywatnych $\mathrm{w}$ dochodach $\mathrm{w}$ okresie starości, emerytura obywatelska wynosi od $6,2 \%$ przeciętnego wynagrodzenia w Islandii do $27,1 \%$ przeciętnej płacy w Australii. Jej poziom jest zatem bardzo zróżnicowany. Podobna sytuacja występuje w porządku (III) obowiązkowych emerytur administrowanych publicznie, gdzie jednolite świadczenie z systemu bazowego wynosi od 11,3\% (Luksemburg) do $31 \%$ (Norwegia) przeciętnego wynagrodzenia. Pod względem samego poziomu emerytury obywatelskiej, jeśli jest już oferowana, trudno jest wyróżnić konkretne porządki emerytalne. Niewątpliwie jednak ten rodzaj świadczenia wy- 


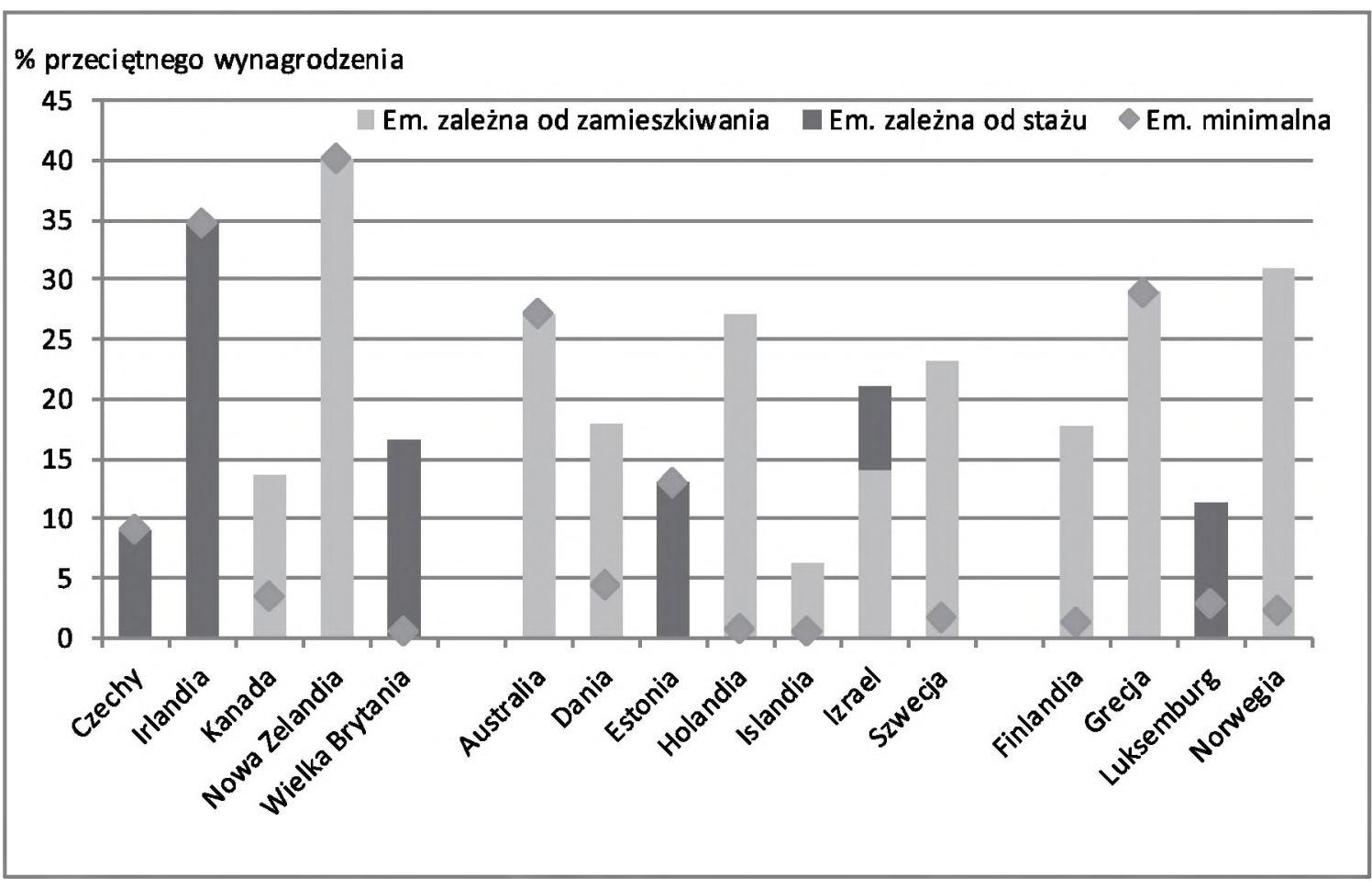

Rysunek 15.1. Poziom emerytury obywatelskiej (zależnej od lat zamieszkiwania lub okresu składkowania) w relacji do przeciętnego wynagrodzenia w wybranych krajach OECD

Źródlo: opracowanie własne na podstawie: [OECD, 2015].

stępuje najczęściej w porządku emerytalnym (I) z istotnym udziałem dobrowolności uczestnictwa.

Emerytura obywatelska i gwarancje świadczeń minimalnych są jednak tylko jednym $\mathrm{z}$ elementów obowiązkowego systemu emerytalnego $\mathrm{w}$ analizowanych krajach. Znacznie lepszych informacji dostarcza porównanie poziomu emerytur obywatelskich i wysokości świadczeń uzyskiwanych z całego systemu obowiązkowego (rys. 15.2). W tym przypadku kraje o istotnym udziale dochodów z prywatnego systemu dodatkowego (porządek emerytalny I) charakteryzują się najniższymi świadczeniami z systemu obowiązkowego w relacji do przeciętnego wynagrodzenia, a jednocześnie relatywnie najwyższym udziałem emerytur obywatelskich $w$ emeryturach bazowych. W Nowej Zelandii i Irlandii jednolita emerytura obywatelska jest jedynym świadczeniem oferowanym w pierwszej części systemu emerytalnego, stąd musi być uzupełniana systemem dodatkowego oszczędzania na starość, aby zapewnić uczestnikom utrzymanie standardu życia po zakończeniu aktywności zawodowej. W Stanach Zjednoczonych i Czechach dominującą rolę w systemie obowiązkowym odgrywa emerytura obliczana na podstawie formuły zdefiniowanego świadczenia (DB), zależna od zarobków, jednak nie w pełni ekwiwalentna i oferująca przeciętnie stopę zastąpienia na poziomie poniżej 50\%. 


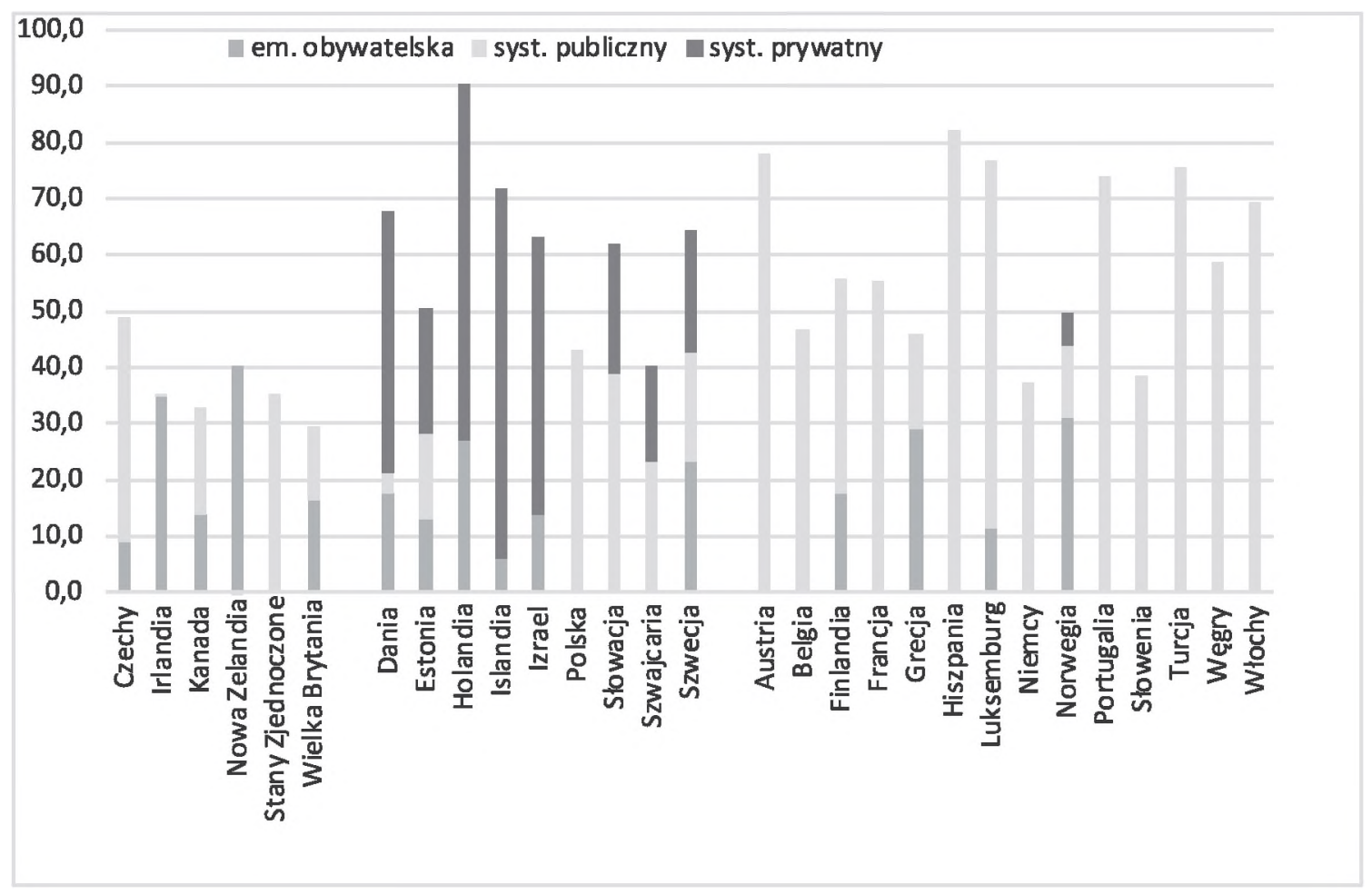

Rysunek 15.2. Emerytura z obowiązkowego systemu emerytalnego w wybranych krajach OECD (jako \% przeciętnego wynagrodzenia)

Źródło: opracowanie wlasne na podstawie: [OECD, 2015].

Kraje tworzące porządek emerytalny (II) charakteryzują się istotnym udziałem zarządzanych prywatnie obowiązkowych planów emerytalnych w systemie obowiązkowym. Co jeszcze istotniejsze, w krajach tych występuje wysoki udział planów o zdefiniowanej składce (DC) w bazowym systemie emerytalnym. Taka sytuacja ma miejsce przede wszystkim w Danii, Izraelu, Polsce i Szwecji, gdzie obowiązkowe emerytury zależne od zarobków są niemal w pełni ekwiwalentne. W tych systemach, poza gwarancjami dopłat do emerytury minimalnej (ewentualnie emeryturą obywatelską), redystrybucję dochodową ograniczono do minimum. W Holandii, Islandii i Szwajcarii występują prywatne systemy obowiązkowe opierające się na rozwiązaniu DB, jednak uzależniające wysokość świadczenia od zarobków i stażu pracy. Ponadto w tych krajach coraz częściej koryguje się na bieżąco parametry występujące w formule DB w zależności od zmiany parametrów demograficznych ${ }^{1}$. Mieszana sytuacja występuje w Estonii i na Słowacji, gdzie publiczne systemy oferujące emeryturę zależną od zebranych punktów są uzupełniane prywatnymi elementami wykorzystującymi formułę DC.

${ }^{1}$ W Szwajcarii niemal co roku podejmowana jest decyzja o wskaźniku procentowym emerytury należnej za każdy rok pracy. 
Kraje reprezentujące porządek (III) obowiązkowych emerytur administrowanych publicznie charakteryzują się relatywnie hojnymi publicznymi emeryturami oferującymi stopę zastąpienia na poziomie od 37,5\% (Niemcy) do 81\% (Hiszpania). Świadczenia są obliczane według formuły zdefiniowanego świadczenia (DB), z wyjątkiem Norwegii i Włoch, w których publiczne systemy są bardziej ekwiwalentne i wykorzystują formułę zdefiniowanej składki (DC).

Formuły emerytalne stosowane w poszczególnych systemach przekładają się w sposób oczywisty na zróżnicowanie stóp zastąpienia. Tam, gdzie system bazowy opiera się przede wszystkim na kwotowej emeryturze obywatelskiej (porządek emerytalny I), zróżnicowanie stóp zastąpienia jest relatywnie duże (rys. 15.3). Zakładając, że świadczenia te są finansowane z podatków lub składek pobieranych w jednakowej wysokości procentowej, świadczy to o występowaniu silnej redystrybucji w kierunku osób mniej zamożnych.

Dosyć duże zróżnicowanie relatywnego poziomu świadczeń występuje także w krajach z porządku emerytalnego (II), w których dobrze rozwinięte są obowiązkowe systemy o zdefiniowanej składce (lub rzadziej o zdefiniowanym świadczeniu) zarządzane przez instytucje prywatne, choć grupa ta jest bardzo niejednorodna. Spadek stopy zastąpienia wraz ze wzrostem dochodu jest widoczny w Australii, Danii, Izraelu i Islandii, w których poza emeryturą składkową (według formuły DC) oferowana jest emerytura obywatelska, oraz w Szwajcarii, w której bazowy system emerytalny oparty jest na formule DB. W tej części krajów występuje redystrybucja w kierunku osób mniej zarabiających. Niemal brak zróżnicowania poziomu emerytur występuje natomiast w systemach emerytalnych Polski, Słowacji, Holandii i Szwecji, co nie oznacza zupełnego braku redystrybucji, lecz jej znacznie mniejszy zakres. Podsumowując, w porządku emerytalnym (II) z istotnym udziałem obowiązkowości uczestnictwa $w$ planach administrowanych przez sektor prywatny, redystrybucja może mieć istotne znaczenie, choć jej siła jest mniejsza niż w krajach należących do porządku emerytalnego (I) i zależy od konkretnych rozwiązań przyjętych w systemach emerytalnych.

Stosunkowo największym zaskoczeniem jest poziom zróżnicowania świadczeń w krajach należących do porządku (III) obowiązkowych emerytur administrowanych publicznie. Dominująca rola obowiązkowego systemu publicznego wykorzystującego formułę o zdefiniowanym świadczeniu (DB) okazuje się dosyć słabo różnicować relatywny poziom świadczeń. Stopy zastąpienia oferowane przez systemy emerytalne w Hiszpanii, Austrii, Turcji, Portugalii, Włoszech, Finlandii, Niemczech oraz na Węgrzech są niemal takie same, niezależnie od poziomu wynagrodzeń. Oznacza to, że formuły DB zawierają jedynie niewielkie elementy socjalne i opierają się na niemal całej historii opłacania składek. Luksemburg, Francja, Norwegia, Grecja, Belgia i Słowenia to natomiast kraje o redystrybucji w kierunku osób uboższych, głównie dzięki oferowaniu emerytury obywatelskiej, która jest następnie 

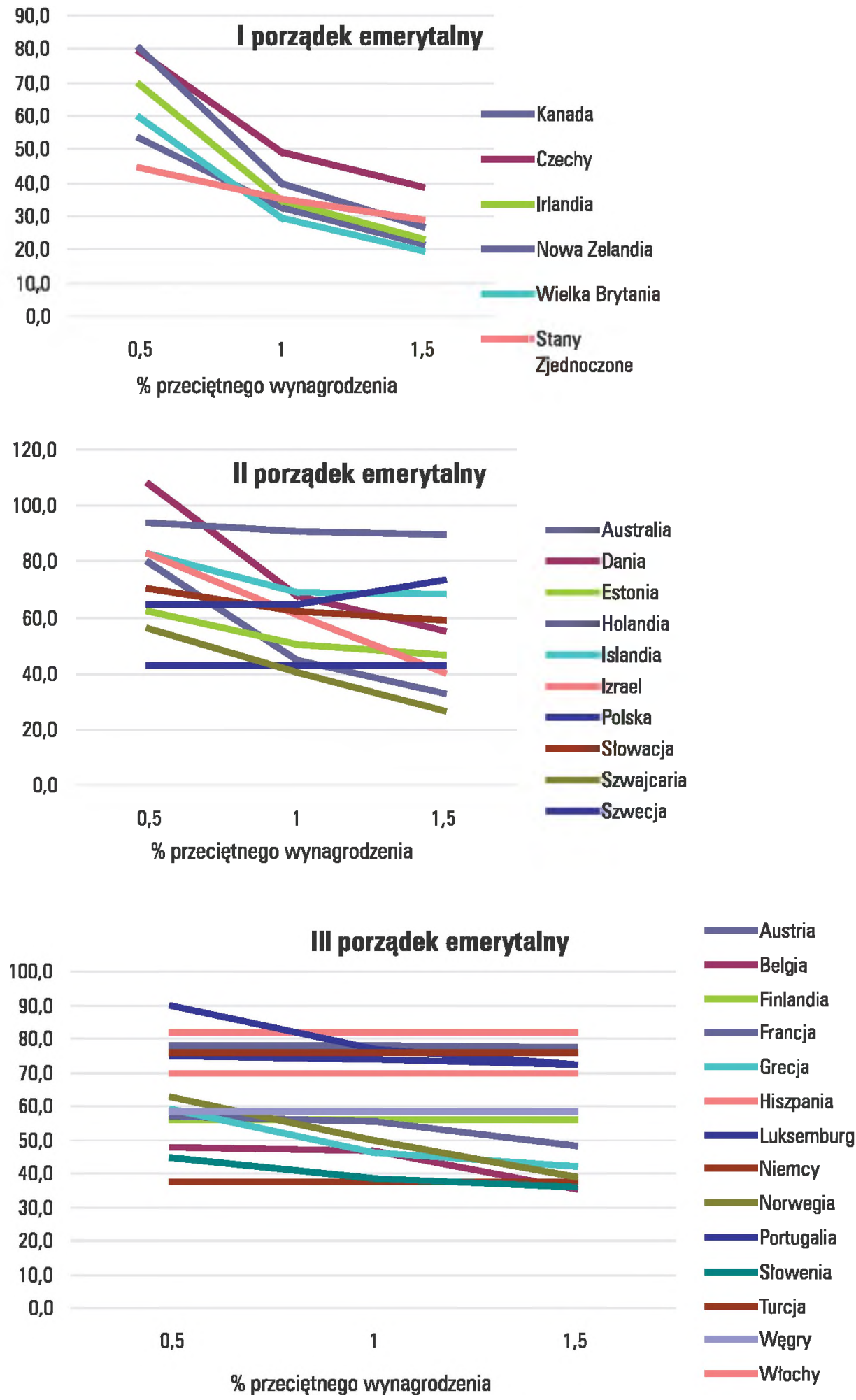

Rysunek 15.3. Zróżnicowanie stóp zastąpienia w zależności od poziomu w wybranych krajach OECD należących do poszczególnych porządków emerytalnych

Źródto: opracowanie wlasne na podstawie danych OECD. 
uzupełniana świadczeniem składkowym z systemu obowiązkowego. W porządku emerytalnym (III) $\mathrm{z}$ istotnym udziałem obowiązkowych planów emerytalnych zarządzanych publicznie, zakres redystrybucji jest niższy niż w porządku (I), co wynika z zastosowanej formuły emerytalnej ( $D B$ vs flat-rate).

Dla pełnego porównania porządków emerytalnych z punktu widzenia ich redystrybucyjności oraz uwzględnienia nie tylko okresu opłacania składek, ale także etapu wypłaty świadczeń, w kolejnym kroku porównane zostaną wskaźniki progresywności oraz poziom i zróżnicowanie przepływów emerytalnych netto. Analiza obejmować będzie jedynie cechy bazowych i obowiązkowych systemów emerytalnych, gdyż takie ograniczenia narzuca zakres dostępnych danych. Pamiętać jednak należy, że dobrowolne systemy emerytalne, nawet jeśli są oferowane według formuły zdefiniowanego świadczenia, charakteryzują się z reguły mniejszym poziomem redystrybucji z uwagi na ściślejsze powiązanie wysokości świadczeń ze stażem pracy $i$ indywidualnym wynagrodzeniem danego pracownika oraz rzadsze występowanie tzw. elementów socjalnych.

Poziom indeksu progresywności zależy od siły, z jaką formuła bazowej emerytury wyrównuje dochody uczestników w okresie starości. 100-procentowe wyrównanie (wskaźnik Pension Gini na poziomie 0\%) oznacza sytuację oferowania równych kwotowo świadczeń $\mathrm{z}$ systemu publicznego dla wszystkich emerytów, niezależnie od poziomu ich wcześniejszych zarobków. Taka sytuacja występuje w systemie emerytalnym Irlandii i Nowej Zelandii. Niemal równe emerytury bazo-

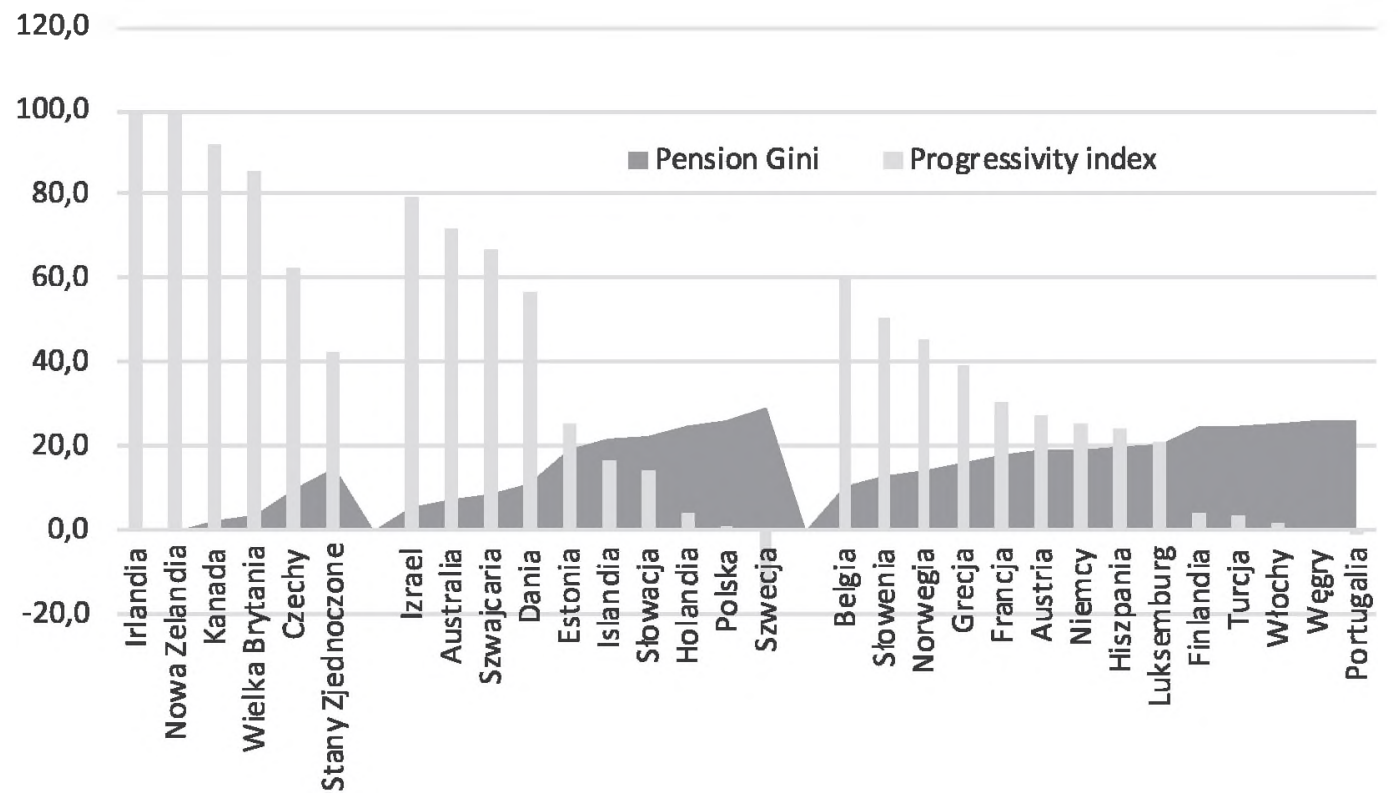

Rysunek 15.4. Wskaźnik Giniego dla dochodów emerytalnych i poziom progresywności systemów emerytalnych wybranych krajów OECD według porządków emerytalnych

Źródto: opracowanie własne na podstawie: [OECD, 2013]. 
we oferowane są także w Kanadzie i Wielkiej Brytanii (indeks progresywności równy odpowiednio 92\% i 85\%), ale także w Izraelu, Australii i Szwajcarii (progresywność na poziomie 60-80\%). Większość krajów należących do porządku emerytalnego (I) posiada zatem systemy o wysokich wskaźnikach progresywności i niskim współczynniku Giniego w odniesieniu do dochodów emerytalnych z systemu publicznego. Wyjątkiem są Stany Zjednoczone, których system emerytalny jest umiarkowanie progresywny, co jest konsekwencją oferowania emerytury w formule DB zależnej od zarobków. Do najbardziej progresywnych nie należy także system czeski, w którym emerytura obywatelska nie jest jedynym i najważniejszym źródłem emerytur publicznych (indeks progresywności na poziomie 62\%).

Druga i trzecia grupa krajów są jeszcze bardziej zróżnicowane. Indeks progresywności przyjmuje tam wartości od 79,5\% w Izraelu do -13,1\% w Szwecji (porządek emerytalny II) oraz od $60,6 \% \mathrm{w}$ Belgii do $-0,8 \% \mathrm{w}$ Portugali (porządek emerytalny III). Ujemne wartości indeksu świadczą o występowaniu regresywności w niektórych systemach emerytalnych, tj. pogłębianiu nierówności dochodowych przez obowiązkowy system emerytalny. W tym wypadku również trudno mówić o relatywnie wyższym lub niższym poziomie progresywności obowiązkowych systemów zarządzanych publicznie lub prywatnie - poziom redystrybucji zależy bowiem od zastosowanej formuły emerytalnej a nie sposobu zarządzania systemem, a w przypadku występowania kilku elementów systemu bazowego - także od ich udziału w dostarczaniu dochodów w okresie starości.

Do podobnych wniosków prowadzi analiza różnic w przepływach emerytalnych netto (rys. 15.5). W krajach oferujących emeryturę obywatelską jako główne świadczenie $\mathrm{z}$ systemu publicznego, występują znaczne różnice $\mathrm{w}$ poziomie przepływów emerytalnych netto w zależności od poziomu dochodów. Najwyższe różnice w transferach, na korzyść osób mniej zarabiających, występują w Nowej Zelandii, Irlandii, Australii, Izraelu, Luksemburgu, Czechach i Norwegii. Najniższą redystrybucją między grupami dochodowymi odznaczają się publiczne systemy emerytalne w Polsce, Turcji, Szwecji i na Węgrzech. Redystrybucja od lepiej do gorzej sytuowanych ma podobny zakres niezależnie od płci.

Wszystkie analizowane kraje i porządki emerytalne cechują się pewnym poziomem redystrybucji od mężczyzn do kobiet. Transfery te są zwykle znacznie niższe niż redystrybucja między grupami dochodowymi i przyjmują podobną wielkość w analizowanych krajach (od 0,6 do 2,2-krotności rocznych zarobków brutto), niezależnie od porządku emerytalnego.

Podsumowując analizę redystrybucyjności systemów emerytalnych zakwalifikowanych do trzech opisanych wcześniej porządków, zaznaczyć należy, że poziom redystrybucji zależy przede wszystkim od zastosowanej formuły emerytalnej. Natomiast konkretne porządki emerytalne wiążą się w sposób oczywisty z częstszym występowaniem (lub większą rolą) wybranych formuł emerytalnych, co ma związek 


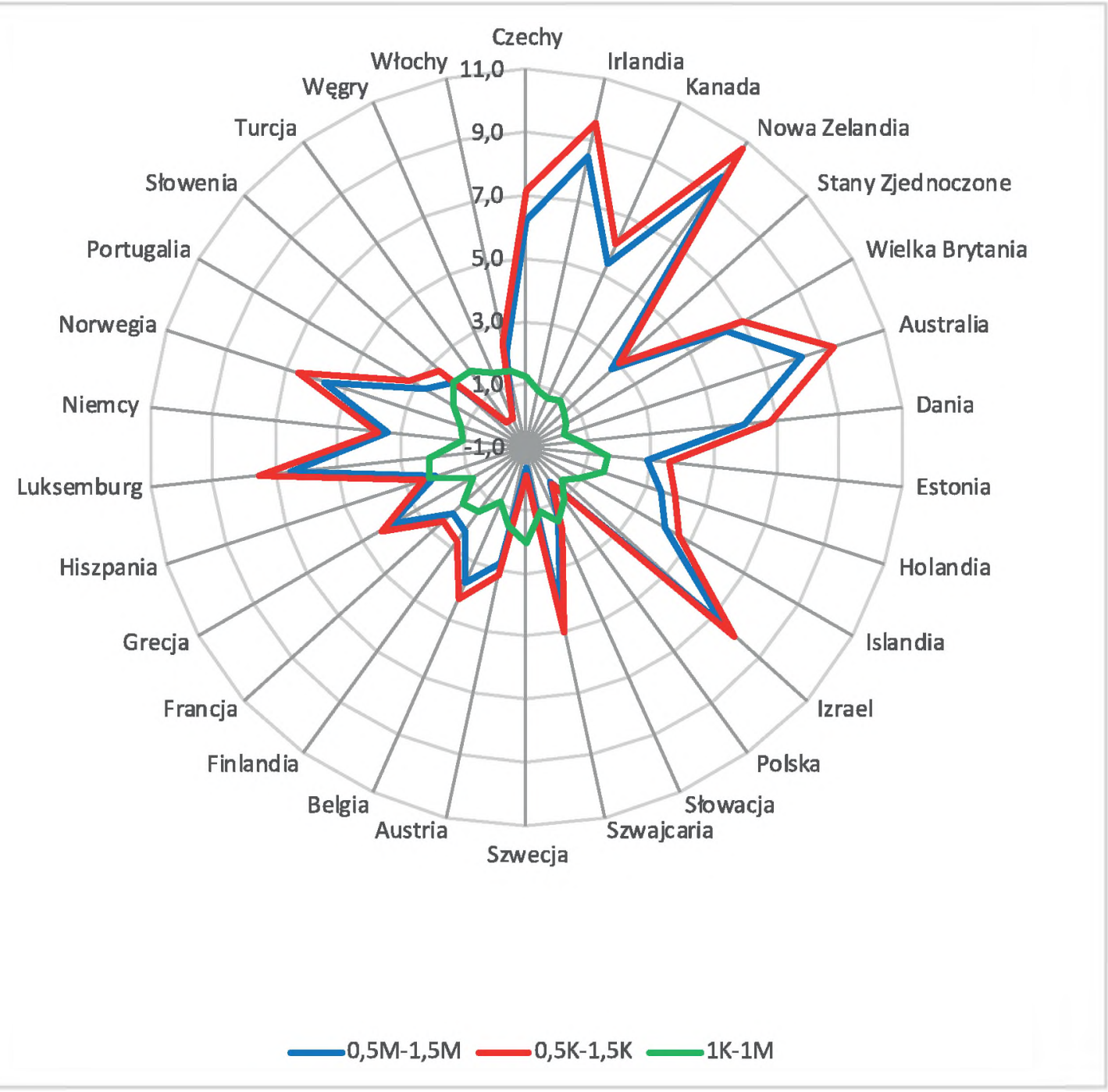

Objaśnienia:

0,5M-1,5M oznacza różnicę między przepływami emerytalnymi netto mężczyzny zarabiającego 50\% i 150\% przeciętnego wynagrodzenia

0,5K-1,5K oznacza różnicę między przepływami emerytalnymi netto kobiety zarabiającej 50\% i 150\% przeciętnego wynagrodzenia

$1 \mathrm{~K}-1 \mathrm{M}$ to różnica w przepływach emerytalnych netto kobiety i mężczyzny zarabiających $100 \%$ przeciętnego wynagrodzenia

Rysunek 15.5. Różnice w przepływach emerytalnych netto osób z różnych grup dochodowych oraz kobiet i mężczyzn w wybranych krajach OECD (jako wielokrotność rocznych dochodów brutto danej osobyl

Źródto: opracowanie własna na podstawie [OECD, 2013]. 
z zakresem i metodami finansowania systemu publicznego oraz jego udziałem w dostarczaniu ogółu dochodów w okresie starości.

Kraje o wysokim udziale dobrowolnych emerytur prywatnych (porządek emerytalny I) charakteryzują się jednocześnie niskim poziomem świadczeń oferowanych przez system obowiązkowy. Prawdopodobnie ów niski poziom zabezpieczenia publicznego poskutkował znacznym rozwojem dodatkowych form oszczędzania na starość, zarówno w formie grupowej, jak i indywidualnej [Rutecka, 2014]. W porządku emerytalnym (I) obowiązkowe stopnie zabezpieczenia emerytalnego tworzą system silnie redystrybucyjny, który opiera się zazwyczaj na formule emerytury obywatelskiej wypłacanej w jednakowej kwocie wszystkim uczestnikom. Transfery występują głównie między grupami dochodowymi, od lepiej do gorzej zarabiających, oraz - w ograniczonym zakresie - od mężczyzn do kobiet. Publiczna część jest zatem wysoce progresywna, jednak cały system (uwzględniając znaczną rolę zabezpieczenia dodatkowego) charakteryzuje się wyraźnie słabszą redystrybucją.

Porządek emerytalny (II) $\mathrm{z}$ istotnym udziałem obowiązkowości uczestnictwa w planach administrowanych przez sektor prywatny obejmuje kraje o wysokim udziale obowiązkowych emerytur zarządzanych prywatnie w ogóle dochodów emerytalnych. W tej grupie dominują rozwiązania obowiązkowe bazujące na formule zdefiniowanej składki lub (rzadziej) zdefiniowanego świadczenia, wsparte emeryturą obywatelską lub gwarancjami emerytury minimalnej. Stopień redystrybucji mierzony zróżnicowaniem świadczeń, indeksem ogólnej progresywności i poziomem przepływów emerytalnych netto kształtuje się tu na bardzo różnym poziomie. Systemy bazujące na zdefiniowanej składce są zwykle mniej redystrybucyjne niż te oparte na zdefiniowanym świadczeniu, co potwierdza przypadek Polski, Szwecji czy Słowacji. Jednak owa niemal czysta ekwiwalentność może być zaburzona przez równoległe wypłacanie relatywnie wysokich emerytur obywatelskich, co ma miejsce chociażby w Australii, Izraelu czy Szwajcarii. Grupa ta nie jest zatem jednorodna. Należy więc uznać, że w porządku emerytalnym (II) w wybranych krajach w ramach systemów obowiązkowych redystrybucja między grupami dochodowymi niemal nie występuje, podczas gdy w innych zbliża się poziomem do wysokich transferów charakterystycznych dla systemów flat-rate lub umiarkowanej redystrybucji obserwowanej w obowiązkowych i zarządzanych publicznie systemach opartych na formule DB.

Ostatnia z wyodrębnionych grup (porządek emerytalny III), tj. kraje o stosunkowo wysokim udziale obowiązkowych emerytur publicznych w całym systemie emerytalnym, charakteryzuje się dominującym wykorzystaniem formuły zdefiniowanego świadczenia (DB) uzupełnionego gwarancjami emerytury minimalnej lub (rzadziej) emeryturą obywatelską. Bazowe systemy emerytalne oferują w tych krajach wysokie stopy zastąpienia, które nie różnią się znacznie między różnymi grupami dochodowymi. W analizowanych systemach emerytalnych występować może 
proces ograniczania redystrybucji przez tzw. reformy parametryczne, co tłumaczyłoby niski poziom zróżnicowania stóp zastąpienia, zbliżony do systemów o zdefiniowanej składce. Przeprowadzane w systemach DB reformy mogą, nie zmieniając całej formuły, wprowadzać elementy zależne od parametrów demograficznych oraz wydłużać okres składkowy, na podstawie którego obliczana jest podstawa wymiaru świadczenia (taką funkcję mogą pełnić także „punkty emerytalne”). Porządek (III) obowiązkowych emerytur administrowanych publicznie charakteryzuje się umiarkowaną redystrybucją od bogatych do biednych w ramach systemu obowiązkowego, oraz niewielką redystrybucją od mężczyzn do kobiet.

Odnosząc się do hipotezy badawczej H3, należy uznać, że analiza porównawcza wskaźników progresywności (rys. 15.4) oraz różnic w przepływach emerytalnych netto osób $\mathrm{z}$ różnych grup dochodowych (rys. 15.5) dostarcza argumentów za jej częściową pozytywną weryfikacją. W zakresie obowiązkowych stopni zabezpieczenia emerytalnego, w ujęciu średnim, największą redystrybucyjnością między grupami dochodowymi charakteryzuje się porządek emerytalny (I), a najmniejszą porządek emerytalny (III). Mniejszy system obowiązkowy skutkuje koniecznością dokonania relatywnie większych transferów w niewielkiej części systemu emerytalnego (ich koncentracji), aby osiągnąć ogólny cel ograniczenia ryzyka ubóstwa wśród osób starszych. Im system obowiązkowy większy, tym relatywnie łagodniejsze mogą być transfery redystrybucyjne, gdyż dotyczą wyższego poziomu świadczeń. Ponadto, wyższa redystrybucja w obowiązkowych systemach zarządzanych publicznie występuje głównie w konsekwencji stosowania formuły DB lub nawet flat-rate, co zdarza się znacznie rzadziej w obowiązkowych systemach zarządzanych prywatnie opartych zwykle na formule DC. Można zatem uznać, że relacja między państwem a rynkiem w systemie emerytalnym (rozumiana dwuwymiarowo: jako relacja między obowiązkowością i dobrowolnością uczestnictwa oraz jako relacja między publicznym i prywatnym administrowaniem/zarządzaniem) wpływa na redystrybucję między grupami dochodowymi, przy czym wpływ ten wynika ze stosowania różnych formuł emerytalnych $\mathrm{w}$ różnych porządkach. Jednocześnie należy podkreślić, że relacja państwo-rynek nie różnicuje w sposób istotny stopnia redystrybucji między mężczyznami i kobietami. Transfery te są znacznie niższe niż redystrybucja między grupami dochodowymi i przyjmują podobną wielkość we wszystkich porządkach emerytalnych. 